\title{
PRODUCTION OF REDUCING SUGARS FROM LIGNOCELLULOSIC KIKUYU GRASS RESIDUES BY HYDROLYSIS USING SUBCRITICAL WATER IN BATCH AND SEMIBATCH REACTORS
}

\author{
PRODUCCIÓN DE AZÚCARES REDUCTORES A PARTIR DE RESIDUOS \\ LIGNOCELULÓSICOS DE PASTO KIKUYU POR MEDIO DE HIDRÓLISIS CON \\ AGUA SUBCRÍTICA EN REACTORES BATCH Y SEMICONTINUOS \\ PRODUÇÃO DE AÇÚCARES REDUTORES DE RESÍDUOS LIGNOCELULÓSICOS DE PASTO \\ KIKUYU POR HIDRÓLISES UTILIZANDO AGUA SUBCRÍTICA EM REATORES BATCH E \\ SEMI-BATCH
}

Paola-Andrea Marulanda-Buitrago ${ }^{1}$ and Víctor-Fernando Marulanda-Cardona ${ }^{1 *}$

'Environmental and Sanitary Engineering Program, Universidad de La Salle, Bogotá, Cundinamarca, Colombia

e-mail: vfmarulanda@unisalle.edu.co

\begin{abstract}
(Received: Aug. 25, 2016; Accepted Aug. 16, 2017)

$\Lambda$ subcritical hydrolysis of Kikuyu grass lignocellulose residues was carried out in batch and semi batch mode operations. Experiments assessed the effect of temperature $\left(250-300{ }^{\circ} \mathrm{C}\right)$, mass ratio $(6: 1$ 30:1), pressure (1 490-3 $190 \mathrm{psi}$ ), and water flow rate $(3-9 \mathrm{ml} / \mathrm{min}$ ) in reducing sugars (RS) yield. Reducing sugar production was measured by means of the DNS method, and efficiency was calculated as the ratio between the mass of produced reducing sugars and the total mass of the residue fed to the reactor. $\mathrm{A}$ maximum RS of $9.7 \%$ was measured in batch hydrolysis experiments at $300{ }^{\circ} \mathrm{C}, 30: 1$ mass ratio and 3190 psi, whereas $22 \%$ accumulated RS yield was obtained in semi batch experiments at $300{ }^{\circ} \mathrm{C}, 2000$ psi and $9 \mathrm{ml} / \mathrm{min}$. The lower yield was attributed to the extended reaction time in batch experiments in comparison to semi batch experiments, in which the reaction time is not only shorter but also the hydrolysis products are continuously removed from the reactor. Analysis of Variance of data for batch experiments showed only the interaction between temperature and mass ratio to be significant, whereas the pressure had no significant effect. A notorious decrease in $\mathrm{pH}$ was measured with increasing reaction times due to the formation of acidic degradation products. The results showed the feasibility of producing reducing sugars from lignocellulosic residues available in large amounts and currently discarded without any utilization through subcritical hydrolysis.
\end{abstract}

Keywords: Subcritical, Hydrolysis, Reducing sugars, Kikuyo grass, Lignocellulose biomass.

How to cite: Marulanda- Buitrago, P.A., Marulanda- Cardona, Victor, F. (2017). Production of reducing sugars from lignocellulosic Kikuyu Grass residues by Hydrolysis using subcritical water in Batch and Semibatch reactors. CT\&F - Ciencia, Tecnología y Futuro, 7(1), 137 - 146. 


\section{RESUMEN}

T e estudió la hidrolisis subcrítica en modo de operación batch y semicontinuo de residuos lignocelulósicos de pasto Kikuyu. Los experimentos evaluaron el efecto de la temperatura $\left(250-300{ }^{\circ} \mathrm{C}\right)$, relación másica (6:1-30:1), presión (1 490-3 190 psi), y flujo de agua (3-9 $\mathrm{ml} / \mathrm{min}$ ) en la productividad de azucares reductores (RS). La producción de azucares reductores se midió por medio del método DNS y la eficiencia se calculó como la relación entre la masa de azucares reductores producida y la masa total de residuo alimentado al reactor. Una productividad máxima de RS de $9.7 \%$ se obtuvo en los experimentos batch a 300 ${ }^{\circ} \mathrm{C}$, relación masa de 30:1 y 3190 psi, mientras que una productividad acumulada de $22 \%$ se obtuvo en los experimentos semibatch a $300^{\circ} \mathrm{C}, 2000$ psi y $9 \mathrm{ml} / \mathrm{min}$. La productividad más baja en los experimentos batch se atribuyó al elevado tiempo de reacción en comparación con los experimentos semibatch, en los cuales el tiempo de reacción no es solo más corto sino que también los productos de la hidrolisis se remueven continuamente del reactor. El análisis de varianza de los datos para los experimentos batch mostró como significativa solo la interacción entre la temperatura y la relación másica, mientras que la presión no tuvo efecto. Una notoria disminución de pH se midió a medida que incrementaba el tiempo de reacción debido a la formación de productos ácidos de degradación. Los resultados demuestran la factibilidad de producir azucares reductores a partir de residuos lignocelulósicos disponibles en grandes cantidades y actualmente desechadas sin ningún aprovechamiento por medio de hidrólisis subcrítica.

Palabras clave: Hidrólisis, Subcrítica, Azucares reductores, Pasto Kikuyo, Biomasa lignocelulósica

\section{RESUMO}

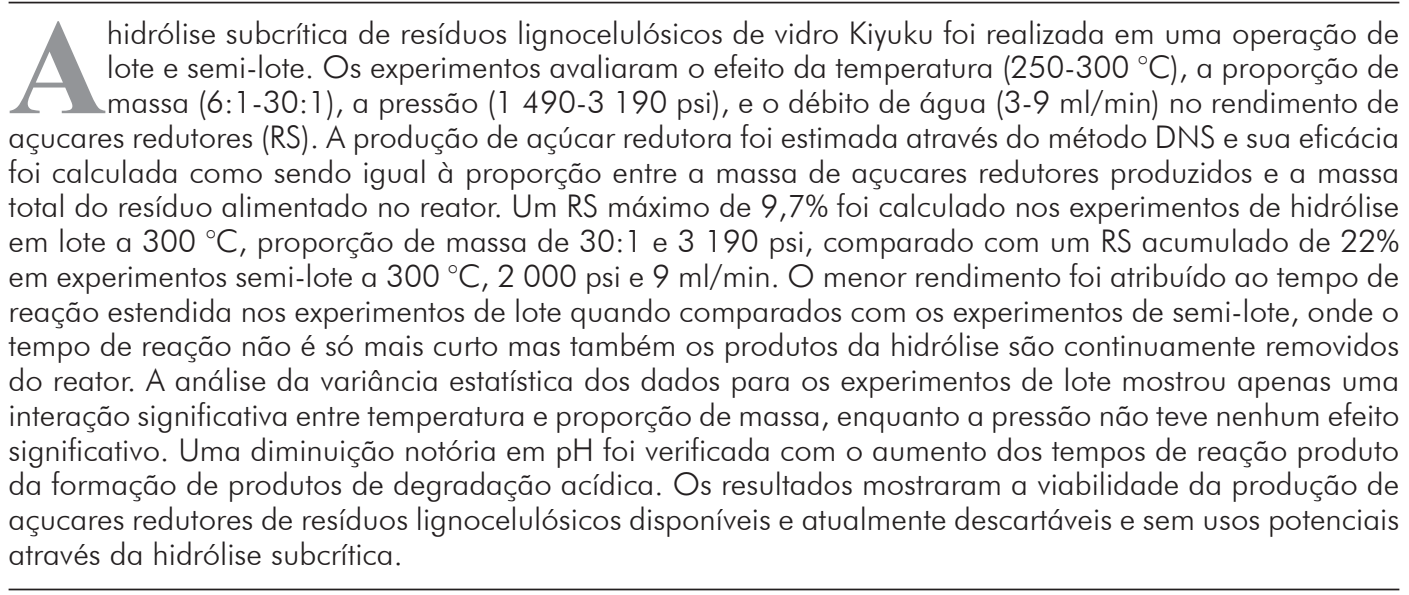

Palavras-chave: Subcrítica, Hidrólises, Açúcares redutores, Pasto Kikuyo, Biomassa lignocelulósica. 


\section{INTRODUCTION}

Kikuyu (Pennisetum clandestinum) lignocellulos residues are produced in large amounts in big cities and are basically discarded to landfills without any potential utilization. For example, in Bogotá (Colombia), around 2500 tons of Kikuyu grass clipping residues were produced during 2016 in maintenance operations of green zones and public spaces (UAESP, 2010). Kikuyu grass is a fast growing forage and must be cut around every 3 weeks. Due to its abundance and cellulose and hemicellulose composition, this lignocellulosic biomass could be employed for the production of reducing sugars, and fermented to produce second generation bioethanol. Nevertheless, studies on its utilization as a biomass for producing reducing sugars are scarce in literature. It is well known that cellulose and hemicellulose can be hydrolyzed to hexoses and siloxes using several processes that mainly involve a physical, chemical, physic-chemical or biological pretreatment (Haghighi et al.,2013), followed by the addition of acid, basic or enzymatic catalyst. However, industrial application of such processes has been limited due to several factors involving the complexity of the process, sugars degradation, corrosion, byproducts formation that prevent the fermentation or poor catalyst recyclability and economic feasibility (Prado et al.,2014). Yet, enzymatic hydrolysis has reached industrial scale production and commercialization. Dupont has a cellulosic ethanol plant in Nevada, which processes corn stover and produces 30 million gallons of fuel grade ethanol annually. It also offers cellulosic ethanol licenses by using a technology that implements enzymes and ethanologens. Also, Abengoa Bioenergy operates a 25 million gallons per year plant since 2014, which utilizes a proprietary enzymatic hydrolysis technology.

In this regard, sub and supercritical water hydrolysis has been reported for the production of reducing sugars from different lignocellulosic residues as a promising alternative to acid and enzymatic hydrolysis. The technology takes advantage of the well-known tunable properties of water in the vicinity or above the supercritical point of water $\left(374{ }^{\circ} \mathrm{C}\right)$. For example, the ionic product of water $\left(K_{w}\right)$ can be manipulated in order to favor or disfavor acid/basis catalysis (Cantero,Tapia, Dolores Bermejo, \& Cocero, 2015), avoiding the use of corrosive acids such as sulfuric and hydrochloric acid commonly employed in the conventional acid catalyzed hydrolysis. As a matter of fact, subcritical water hydrolysis has been regarded as a clean and fast hydrolysis method with the advantages of no pretreatment required, shorter reaction time due to high temperature conditions, less corrosion and avoidance of catalyst residue generation, as well as lower formation of degradation products (Prado et al., 2015).

Several subcritical and supercritical water hydrolysis studies have been conducted through batch, semi batch and continuous mode operations with different lignocellulose residues, as recently reviewed in detail by Prado et al (2015). In batch mode, biomass and water are charged simultaneously to the reactor, heated up and left to react for a specific time. Since no product is removed during the reaction, produced sugars could be easily degraded. In a semi batch operation, a fixed amount of lignocellulosic biomass is charged to the reactor and water flows continuously, removing reaction products to avoid degradation. Data from semi batch reactors may be transferred to industrial scale reactors (Schacht, Zetzl, \& Brunner, 2008). Batch and semi batch experiments are usually carried out in the temperature range of 180 ${ }^{\circ} \mathrm{C}$ to $230{ }^{\circ} \mathrm{C}$. Continuous processes simultaneously pump up water and lignocellulosic biomass as slurry to the reactor. Since it is easier to adjust the residence time in the reactor, supercritical water conditions at very short reaction times have been preferred (Cantero, Dolores Bermejo, \& Cocero, 2013). Corn stover, corn stalks, sugarcane bagasse and rice bran are the most widely used lignocellulosic residues in subcritical or supercritical hydrolysis experiments, which can be attributed to its relatively high content of cellulose and abundance. Yet, hydrolysis rates and yield will depend not only on cellulose and hemicellulose composition, but also will depend on cell wall composition, structure and lignin content. Therefore, each lignocellulosic material represents a technological challenge that needs to be address individually (Prado et al., 2015).

Accordingly, in this work we report on the production of reducing sugars by subcritical water treatment of Kikuyu grass clipping residues in batch and semi batch reactors. Although cellulose and hemicellulose content of this residue is inferior to other kinds of lignocellulosic biomasses, its abundance and accessibility make it an attractive raw material to produce high added-value products such as bioethanol. 


\section{EXPERIMENTAL DEVELOPMENT}

\section{Lignocellulose residues}

Kikuyo grass clipping residues were collected from Universidad de La Salle campus in Bogotá, Colombia, during garden maintenance operations, comminuted in a knife mill (Cole-Parmer IKA analytical mill IL USA) and sieved below $400 \mu \mathrm{m}$, as shown in Figure 1. Comminuted grass samples were stored in a freezer (Cole-Parmer Marvel Scientific Refrigerator 24" IL USA) without any other pre-treatment. Reported residues humidity is $73 \%$ (UAESP, 2010). Lignocellulosic residue composition of kikuyu grass, corn stover and sugarcane bagasse, are shown in Table 1 for comparison purposes. While cellulose and hemicellulose composition in Kikuyu grass is inferior to other kinds or lignocellullosic residues, lignin content is considerably lower. Lignin is a specially problematic component of agricultural residues (Prado et al., 2014). Decomposition of lignin produces phenolic compounds, which strongly inhibit the action of yeast (Schacht et al., 2008).

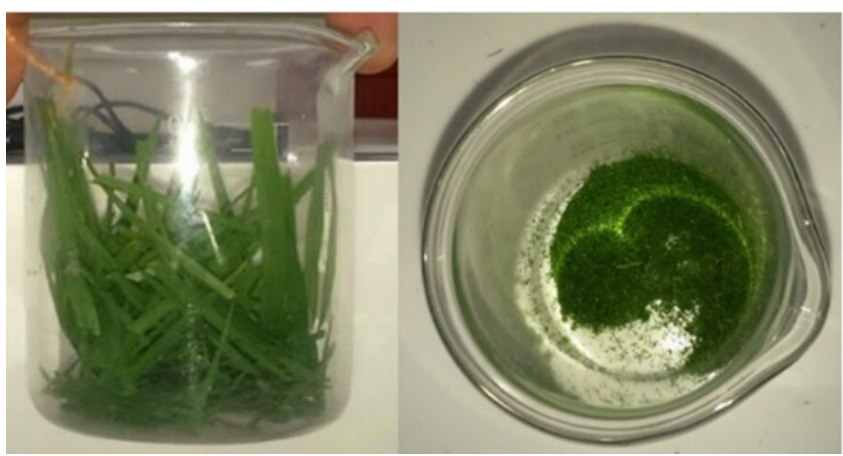

Figure 1. Kikuyu grass clipping residues

\section{Experimental subcritical hydrolysis apparatus}

Experimental runs were conducted in batch reactor equipment and a semi batch lab scale unit. The reactor was made of 316SS Swagelok tubing 0.5 in O.D (1.27 $\mathrm{cm}), 0.065$ in $(0.17 \mathrm{~cm})$ wall thickness, length of $10 \mathrm{~cm}$ and volume of $6.94 \mathrm{~cm}^{3}$. In batch experiments, a fixed amount of comminuted biomass and water, calculated according to the mass ratio for a specific run and the expected water pressure calculated at reaction conditions through steam tabs, were loaded to the reactor and sealed with screw-caps. Then the reactor was placed in an electrical insulated oven previously heated at the desired reaction temperature, as shown in Figure 2.

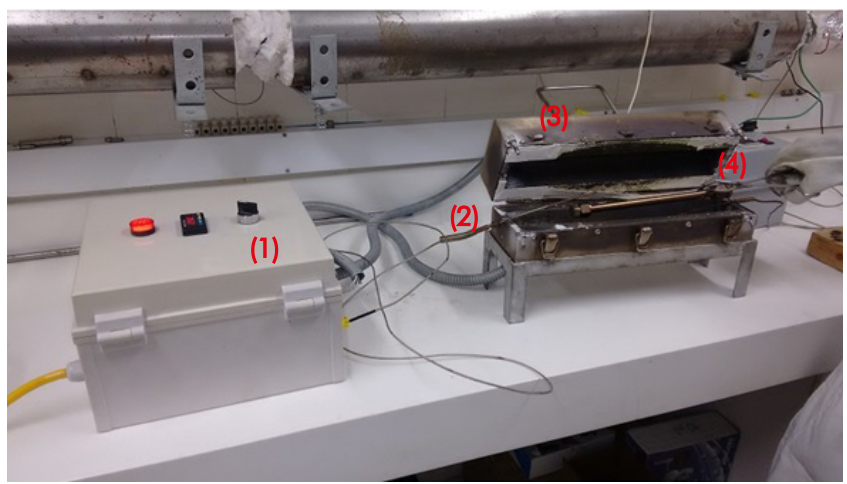

Figure 2. Batch experimental setup. (1) PID temperature controller, (2) K type Thermocouple, (3) Insulated high temperature oven, (4) 1/2" tubular reactor

The semi batch lab scale unit consisted of a deionized water tank, a Williams Milton Roy (PA, USA) pneumatic high pressure pump model CP250V225, a preheater made of $316 \mathrm{SS}$ Swagelok tubing $1 / 8$ in O.D $(3.175 \mathrm{~mm})$, length of $3 \mathrm{~m}$ coiled tubing and electrical resistances, an insulated tubular reactor with a length of $10 \mathrm{~cm}$, a concentric tube heat exchanger with water as cooling media, designed and constructed at Universidad de la Salle, a needle depressurization model SS-1RS4 (Swagelok, Barranquilla Colombia) valve and sample collection recipient, pressure gauges (Ashcroft CT, USA) and thermocouples, as shown in Figure 3

Table 1. Lignocellulosic residue composition of Kikuyu grass, corn stover and sugarcane bagasse

\begin{tabular}{|c|c|c|c|c|}
\hline Lignocellulosic biomass & Cellulose wt $\%$ & Hemicellulose wt \% & Lignin wt \% & Source \\
\hline Kikuyu grass & 26.9 & 26,2 & 5,6 & (Cardona \& Rios, 2012) \\
\hline \multirow{2}{*}{ Corn stover } & 38.3 & 25.8 & 17.4 & (Haghighi Mood et al., 2013) \\
\hline & 34.5 & 27.7 & 17.8 & (Kumar et al., 2011) \\
\hline \multirow{2}{*}{ Sugarcane bagasse } & 43.1 & 31.1 & 11.4 & (Cardona \& Rios, 2012) \\
\hline & 35 & 35.8 & 16.1 & (Sasaki et al., 2003) \\
\hline
\end{tabular}




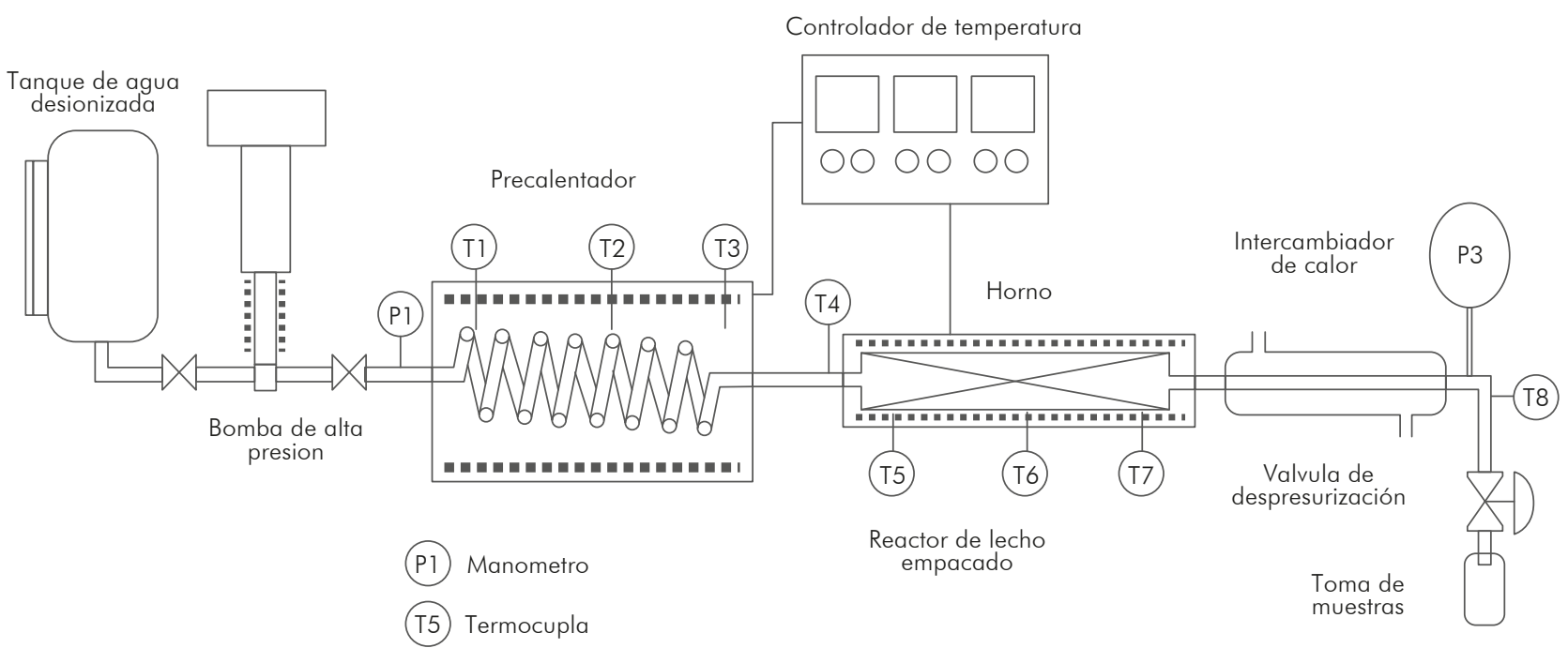

Figure 3. Semi batch lab scale unit

In a typical run, the reactor is removed from the system and packed with a fixed amount of 2 to $4 \mathrm{~g}$ comminuted lignocellulosic biomass. Glass beads are also added to the reactor to avoid biomass compaction and plugging. Once the reactor was put back in place, the system is pressurized with water at room temperature up to 2000 psi to avoid water phase change during the heating up period at subcritical hydrolysis conditions. Once the temperature in the preheater is constant, pumping is started and pressure is adjusted through the needle valve. Samples are collected in sample tubes each 1 or 2 minutes. Pneumatic pump frequency and piston length was adjusted to have deionized water flowrates of 3 and $9 \mathrm{ml} / \mathrm{min}$. The effect of reactor volume in result's reproducibility was not assessed at this time of the research. Yet, it is expected to draw insights on the water flow rate and residence time from runs.

\section{Analytical methods}

Reducing sugars (RS) determination, which accounts for hexoses and pentoses produced from cellulose and hemicellulose fractions, was measured in hydrolysate samples by the dinitrosalicylic (DNS) colorimetric method using d-glucose as standard (Panreac, Barcelona Spain) (Miller, 1959). For batch experiments, the RS was measured at the end of the batch reaction time, whereas in semi batch, runs were measured in samples taken every 1 or 2 minutes. Briefly, for each $\mathrm{ml}$ of hydrolysate sample, $1 \mathrm{ml}$ DNS reagent previously prepared was added, boiled for $15 \mathrm{~min}$, and $1 \mathrm{ml}$ deionized water added afterwards to keep for 10 min in cold water before reading the absorbance in a Macherey-Nagel Nanocolor $500 \mathrm{D}$ photometer at $540 \mathrm{~nm}$. The concentration of reducing sugars was calculated based on a standard curve obtained with glucose concentrations of up to 1 $\mathrm{mg} / \mathrm{ml}$. RS yield in batch experiments was calculated with the total water volume loaded to the reactor and the lignocellulosic biomass loaded to the reactor, whereas in semi batch experiments the volume of each sample and its respective RS concentration were measured to calculate the total mass. RS method does not distinguish hexoses from pentoses. To do so, HPLC analysis with standards for each sugar is required. Yet, this was not carried out at this stage of the research. The organic acids formation, which might potentially inhibit fermentation reactions, was also verified by means of the $\mathrm{pH}$ of hydrolysate samples using a digital WTW pH meter 315i.

\section{Statistical analysis}

Batch experimental runs were planned according to a $2^{\mathrm{k}}$ full factorial design with factors temperature (A), pressure (B) and water to biomass mass ratio (C), using reducing sugars yield as a response variable. Low and high levels for each factor $(-1,+1)$ were selected according to preliminary experiments. Thus, levels for temperature were 250 and $300{ }^{\circ} \mathrm{C}$, pressures of 1450 and $3190 \mathrm{psi}$ and 6:1 and 30:1 weight/weight, reaction time was kept constant at $30 \mathrm{~min}$. The design is comprised by 8 experimental runs, made in a randomized order. 
Statistical analysis of the results was made according to the analysis of variance (ANOVA), as well as the graphical analysis of the significant main effects and interactions plots, by using the statistical software package Minitab 16®.

\section{RESULTS AND DISCUSSION}

\section{Subcritical batch hydrolysis experiments}

Table 2 summarizes batch hydrolysis experimental conditions and the obtained reducing sugars yield (wet basis). A maximum yield of $9.7 \%$ was measured at 300 ${ }^{\circ} \mathrm{C}, 30: 1$ water to biomass ratio and 3190 psi. However, RS concentrations were generally higher when working with a 6:1 mass ratio due to the increased biomass amount loaded to the reactor. Not all of the experimental runs but some were replicated, as indicated in concentration and RS yield columns in Table 2. Yield in replicated runs was expressed as the mean value and the standard deviation. Although deviation was as high as 2 in some runs, the results showed that repeatability was generally good for a batch reactor. Yet, only the first data was used for the ANOVA analysis. Table 3 shows RS yield production from different raw materials by batch hydrolysis at similar subcritical conditions (wet basis). The 9.7\% yield obtained through batch experiments is high when considered cellulose and hemicellulose content in Kikuyu grass. However, a direct comparison is not entirely appropriate because yield will depend not only on cellulose and hemicellulose biomass composition but also on different factors such as lignin content, biomass pretreatment, heating rate and heating time, reactants mass ratio and soluble sugars initially present in the raw material.

Table 2. Summary of batch reaction conditions

\begin{tabular}{|c|cccc|}
\hline $\begin{array}{c}\text { Temperature } \\
\left({ }^{\circ} \mathrm{C}\right)\end{array}$ & $\begin{array}{c}\text { Mass } \\
\text { ratio }\end{array}$ & $\begin{array}{c}\text { Pressure } \\
(\mathrm{psi})\end{array}$ & $\begin{array}{c}\text { Concentration } \\
(\mathrm{mg} / \mathrm{ml})\end{array}$ & $\begin{array}{c}\text { RS yield } \\
\%\end{array}$ \\
\hline 250 & 6 & 1450 & $15.0 / 13.5$ & $8.6 \pm 0.6$ \\
\hline 250 & 6 & 3190 & 10.8 & 6.5 \\
\hline 250 & 30 & 1450 & $1.3 / 2.2$ & $5.2 \pm 2$ \\
\hline 250 & 30 & 3190 & $1.5 / 2.4$ & $5.8 \pm 2$ \\
\hline 300 & 6 & 1450 & 7.1 & 4.3 \\
\hline 300 & 6 & 3190 & 6.1 & 3.7 \\
\hline 300 & 30 & 1450 & $2.7 / 1.8$ & $6.7 \pm 2$ \\
\hline 300 & 30 & 3190 & $3.2 / 2.5$ & $8.5 \pm 1.7$ \\
\hline
\end{tabular}

Table 3. yield from different raw materials by batch hydrolysis

\begin{tabular}{|l|c|c|c|}
\hline $\begin{array}{c}\text { Raw material } \\
\text { Cellulose/ } \\
\text { hemicellulose }\end{array}$ & $\begin{array}{c}\text { Reaction } \\
\text { conditions }\end{array}$ & $\begin{array}{c}\text { RS yield } \\
\text { concentration }\end{array}$ & Reference \\
\hline $\begin{array}{c}\text { Kikuyo grass } \\
26.9 \% / 26.2 \%\end{array}$ & $300^{\circ} \mathrm{C}, 3190 \mathrm{psi}$ & $8.5 \%$ & This work \\
\hline $\begin{array}{c}\text { Wheat straw } \\
21.7 \% / 11.7 \%\end{array}$ & $280^{\circ} \mathrm{C}, \mathrm{NA}$ & $6.7 \%$ & $\begin{array}{c}\text { (Zhao et al., } \\
\text { 2009) }\end{array}$ \\
\hline $\begin{array}{c}\text { Corn stover } \\
34.5 \% / 27.7 \%\end{array}$ & $170^{\circ} \mathrm{C}, 4350 \mathrm{psi}$ & $4.91 \%$ & $\begin{array}{c}\text { (King et al., } \\
\text { 2012) }\end{array}$ \\
\hline $\begin{array}{l}\text { Rapeseed straw } \\
49.48 \% / 14.55 \%\end{array}$ & $255^{\circ} \mathrm{C}, 1450 \mathrm{psi}$ & $18 \%$ & $\begin{array}{c}\text { (Pińkowska et al., } \\
\text { 2013) }\end{array}$ \\
\hline
\end{tabular}

Figures 4 and 5 show the normal probability plot of the residuals and the normal plot of stardardized effects for data in Table 2. As can be observed in Fig. 4, the normal probability plot of the residuals resembles a straight line. Therefore, the error distribution is normal. Figure 5 shows only the interaction between temperature and the reactants mass ratio has a significant effect on the response, with a P-value of 0.017 , whereas the reaction pressure had no significant effect, and a model regression coefficient $\mathrm{R}^{2}=89.06 \%$ according to the performed Minitab ANOVA analysis.

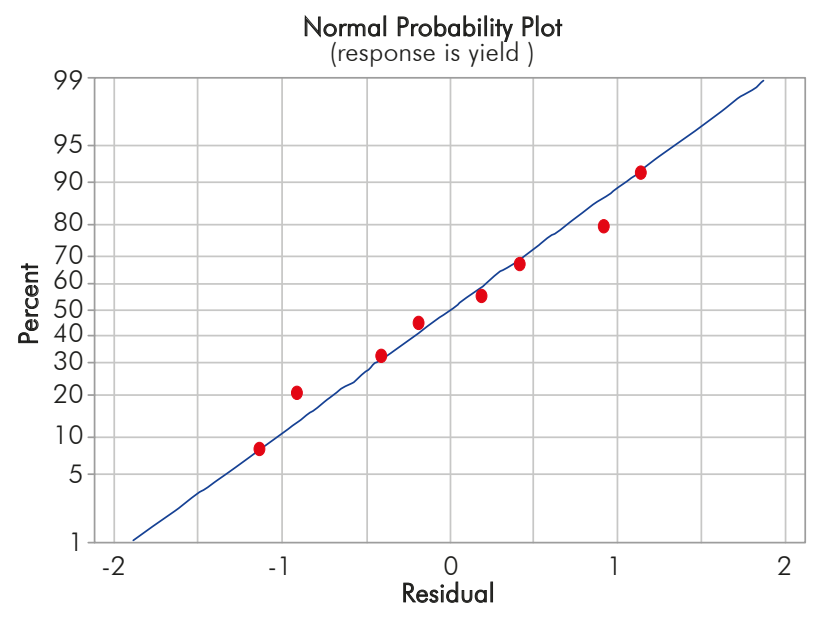

Figure 4. Normal probability plot of the residuals for data in Table 2

The interaction plot $\mathrm{AC}$, temperature-mass ratio, is shown in Figure 6. It can be observed that the highest yields are obtained when working at $300{ }^{\circ} \mathrm{C}$ and $30: 1$ water to biomass ratio, which could be attributed to the higher reaction temperature speeding up the reaction when compared to the experiments with the same ratio at lower temperature. High yields are also obtained at $250{ }^{\circ} \mathrm{C}$ and a $6: 1$ mass ratio, which could be attributed to the higher biomass amount loaded to the reactor. Yet, 


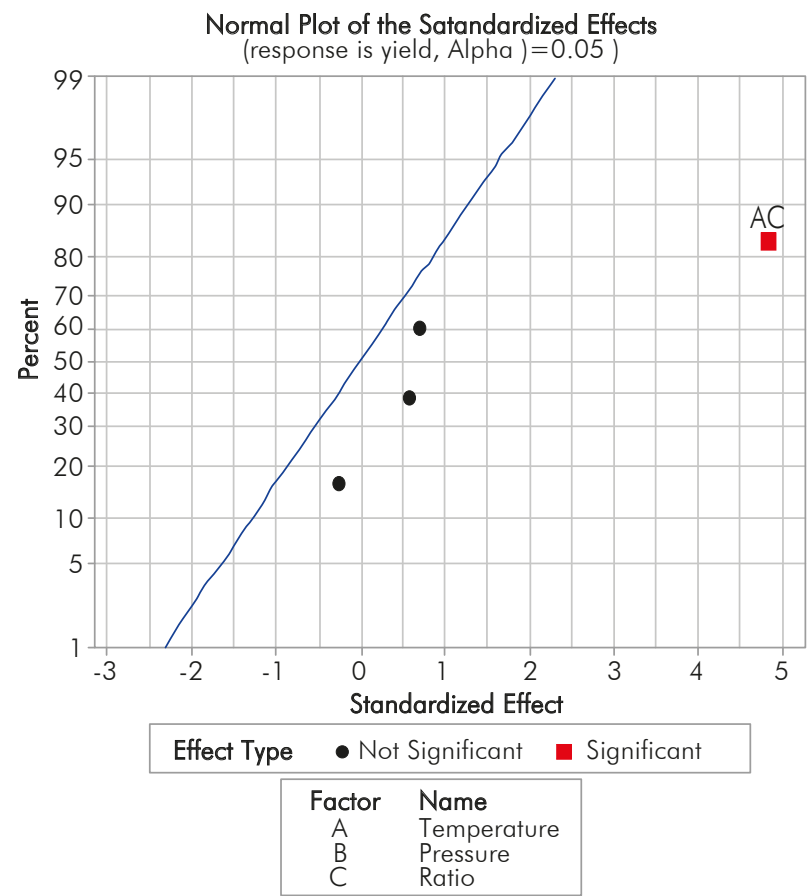

Figure 5. Normal plot of standardized effects for data in Table 2

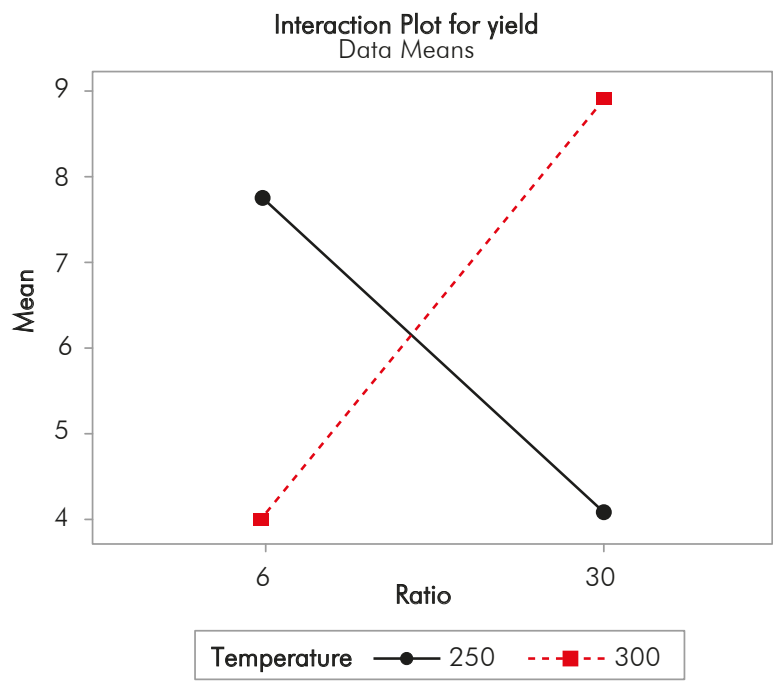

it rapidly decreases upon increasing the temperature to $300{ }^{\circ} \mathrm{C}$ possibly explained by sugars degradation

\section{Subcritical semi batch hydrolysis experiments}

Semi batch subcritical hydrolysis experiments were carried out at temperatures between 240 and $300{ }^{\circ} \mathrm{C}$, pressures up to $2000 \mathrm{psi}$ and water flowrates of 3 and 9 $\mathrm{ml} / \mathrm{min}$. A fixed amount of 2-4 $\mathrm{g}$ of kikuyu grass biomass together with glass beads were packed in the reactor for each run. Reactor effluent samples were taken every 2 minutes right after the pumping was started. Figure 7 shows the effluent color for the run conducted at 275 ${ }^{\circ} \mathrm{C}, 1500 \mathrm{psi}$ and $3 \mathrm{ml} / \mathrm{min}$. At first, effluent samples are clear but soon after they developed a brownish color and pleasant sugary odor that could be directly related to reducing sugars concentration through the DNS method; the darker the brown color the higher the measured absorbance or RS concentration in the obtained hydrolysate at that specific reaction time. After some time has passed effluent samples turned clear again, which served as an indicative of the end of the run because of the depletion of lignocellulosic biomass in the reactor. After the pumping was stopped, the reactor was removed from the system to check the residue left. In some runs, there was practically no biomass left, only the glass beads, which means all cellulosic material was converted. RS concentration was measured in each sample taken, and sugar mass was calculated with the measured concentration and sample volume in order to approach the accumulated reducing sugar mass with time for each experimental run. Due to the large number of samples taken for RS analysis in each semi batch run, no replication was carried out. Reducing sugars accumulated per $100 \mathrm{~g}$ of biomass for each run are displayed in Figures 8 and 9.

Figure 6. Interaction plot AC, temperature-mass ratio

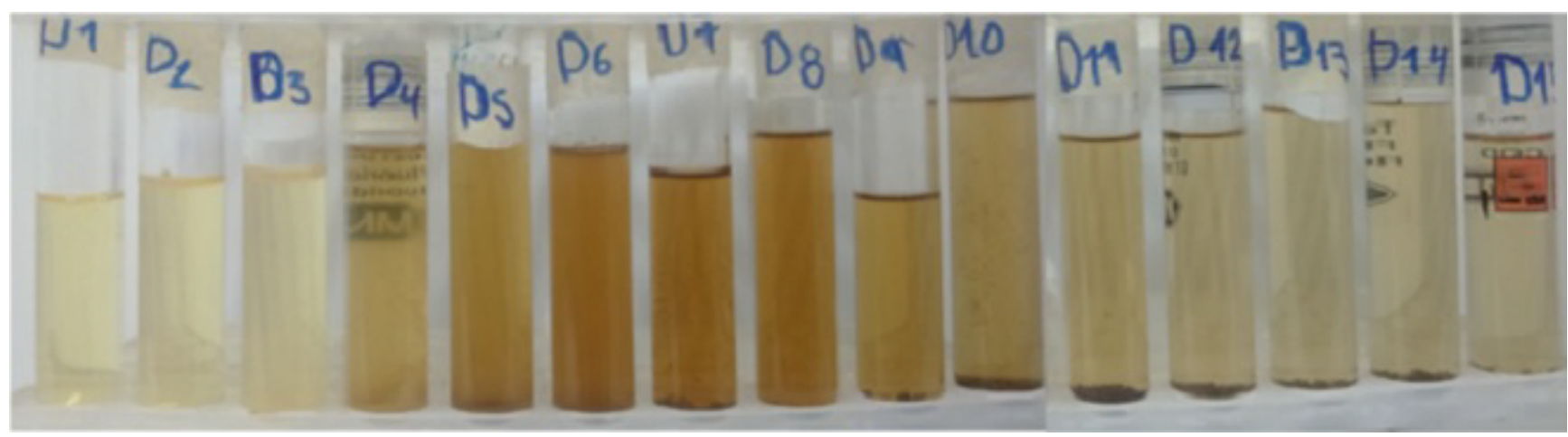

Figure 7. Aspect of effluent samples of semi batch run carried out (left to right) at $275^{\circ} \mathrm{C}, 1500 \mathrm{psi}$ and $3 \mathrm{ml} / \mathrm{min}$ 


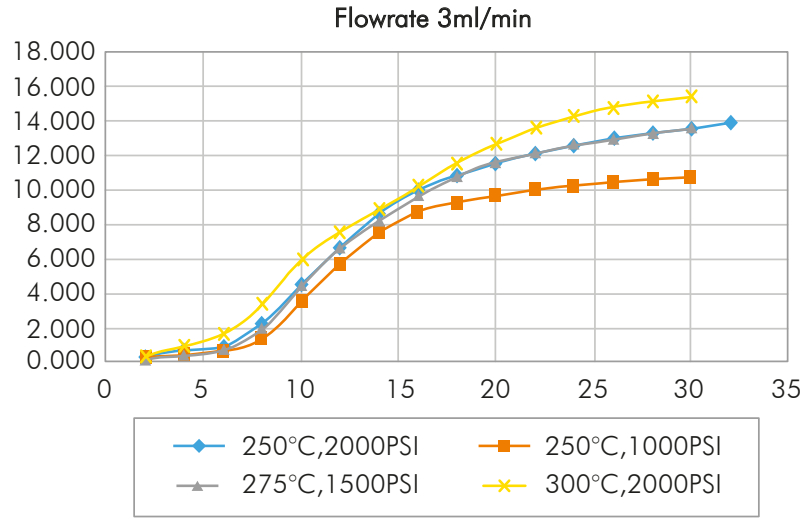

Figure 8. Reducing sugar accumulated with hydrolysis time in semi batch runs with $3 \mathrm{ml} / \mathrm{min}$

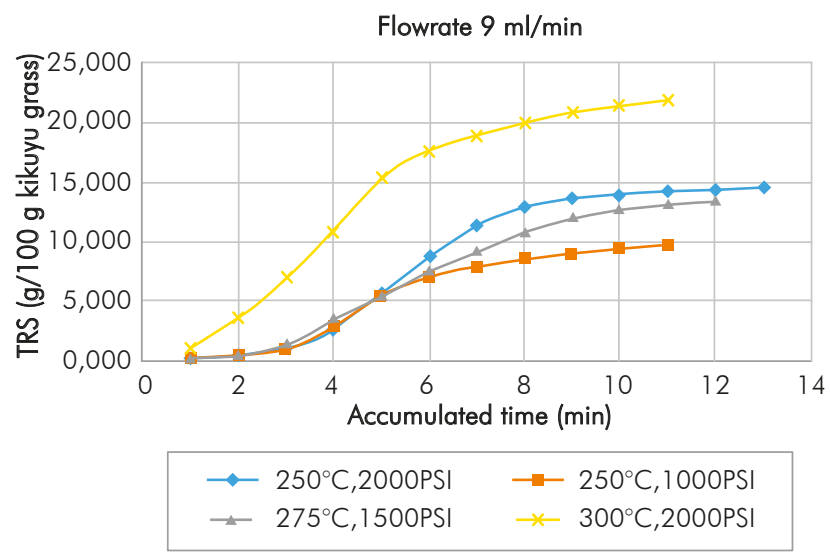

Figure 9. Reducing sugar accumulated with hydrolysis time in semi batch runs with $9 \mathrm{ml} / \mathrm{min}$

Figures 8 and 9 shows that reaction times for runs with water flowrates of $3 \mathrm{ml} / \mathrm{min}$ and $9 \mathrm{ml} / \mathrm{min}$ were around 30 and 12 min whereas highest RS yields of $15 \%$ and $22 \%$, were obtained at $300{ }^{\circ} \mathrm{C}$ and $2000 \mathrm{psi}$, respectively. The maximum yield of $22 \%$ is considerably higher than the yield obtained by batch hydrolysis at $300{ }^{\circ} \mathrm{C}$, which could be attributed to reducing sugar decomposition in comparison to the rapid removal and cooling of formed RS in the semi batch reactor setup. As also shown by Prado (2014), the higher the flowrate the higher the RS yield, probably due to the lower residence time in the reactor, which decreases the time for sugar degradation. Table 4 shows a comparison of reaction conditions and RS yields reported for semi batch subcritical hydrolysis experiments with different raw materials (wet basis). Obtained yield of $22 \%$ through semi batch experiments is similar to figures reported in other studies that utilize biomass sources with higher cellulose and hemicellulose fractions.

It is well known that produced reducing sugars, either in semi batch or batch reactor setups, are prone to degradation, raising concerns not only for productivity loss but also for the formation of by products such as furfural, hydroxymethyl furfural, acetic acid, acrylic acid, formic acid, glycolic acid, to name only a few, that could prevent the fermentation process as it is usually carried out (Mussatto \& Roberto, 2004). Fermentability of produced sugars by subcritical water has been addressed in a few studies. For example, Abdelmoez et al. (2014) studied the subcritical hydrolysis of wheat straw, and under optimum hydrolysis conditions obtained 51.5 $\mathrm{wt} \% \mathrm{RS}$, from which $3.2 \%$ were glucose, $7.6 \%$ xylose and the rest other polysaccharides. A hydrolysate sample was fermented by using Saccharomices Cerevisiae baker yeast, and ethanol production was higher than the theoretical expected from glucose only, which was attributed to the presence of glucose oligomers not accounted for, or the fermentation of some of the xylose.

Decomposition of lignin produces phenolic compounds which strongly inhibit the action of yeast (Schacht et al., 2008). In order to assess the formation of acidic degradation byproducts, the $\mathrm{pH}$ of hydrolysates was taken every two minutes and was also measured, and it was found to decrease with the increase of the total time in semi batch runs as shown in Figure 10 for runs carried out with a water flowrate of $9 \mathrm{ml} / \mathrm{min}$.

Table 4. RS yield from different lignocellulosic materials by semi batch subcritical hydrolysis

\begin{tabular}{|c|ccc|}
\hline $\begin{array}{c}\text { Raw material } \\
\text { Cellulose/hemicellulose } \\
\text { Kikuyo grass (this work) } 26.9 \% / 26.2 \%\end{array}$ & Reaction conditions & RS yield concentration & Reference \\
\hline Sugar cane bagasse $35 \%,>30 \%$ & $194-214^{\circ} \mathrm{C}, 2900 \mathrm{psi}, 33 \mathrm{ml} / \mathrm{min}$ & $22 \%$ & This work \\
\hline Coconut husk & $259{ }^{\circ} \mathrm{C}, 2900 \mathrm{psi}, 33 \mathrm{ml} / \mathrm{min}$ & $11.7 \%$ & (Prado et al., 2014) \\
\hline Palm fiber & $250{ }^{\circ} \mathrm{C}, 2175 \mathrm{psi}$ & $23 \%$ & (Prado et al., 2014) \\
\hline
\end{tabular}




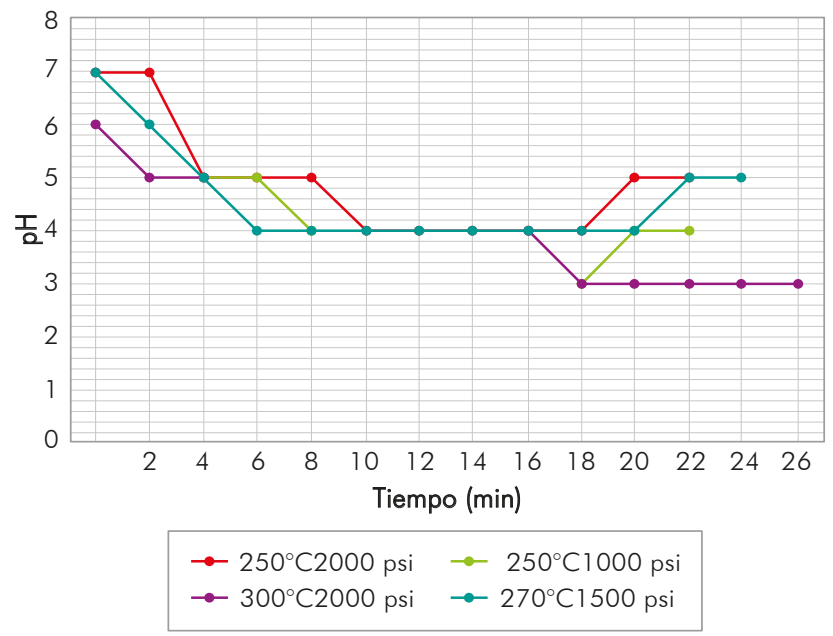

Figure 10. $\mathrm{pH}$ of hydrolysates by semi batch hydrolysis with flowrate of $9 \mathrm{ml} / \mathrm{min}$

In Figure 10 can be observed that $\mathrm{pH}$ rapidly drops with the semi batch total reaction time, reaching a minimum of 3 in the run carried out at $300^{\circ} \mathrm{C}$ and 2 $000 \mathrm{psi}$, which is also the run with the highest RS yield. Yet, degradation byproducts, not only from sugars degradation but also from lignin and compounds derived from the cellulosic structure, are not an issue exclusive to subcritical or supercritical hydrolysis experiments, but also to conventional acid catalyzed processes. In this regard, several biological, physical and chemical technologies have been proposed to detoxify or reduce the concentration of these compounds in lignocelllosic hydrolysates, as extensively reviewed in literature (Mussatto \& Roberto, 2004).

\section{CONCLUSIONS}

- Hydrolysis using subcritical water in batch and semi batch configurations was applied in order to assess the effect of temperature, biomass to water mass ratio, pressure and water flowrate in the yield of reducing sugars obtained from cellulose and hemicellulose fractions in Kikuyo grass. A maximum yield of 9.7 $\%$ was measured at $300{ }^{\circ} \mathrm{C}, 30: 1$ water to biomass ratio and 3190 psi in batch experiments, whereas a yield of $22 \%$ was measured at $300^{\circ} \mathrm{C}, 2000 \mathrm{psi}$ and water flowrate of $9 \mathrm{ml} / \mathrm{min}$ in semi batch experiments. ANOVA analysis showed only the interaction between temperature and mass ratio to be significant, whereas the pressure had no significant effect. Semi batch experiments with water flow rates of 3 and 9 $\mathrm{ml} / \mathrm{min}$ showed that the higher the flow rate the higher the RS yield, and a maximum of $22 \%$ was measured at $300{ }^{\circ} \mathrm{C}, 2000 \mathrm{psi}$ and $9 \mathrm{ml} / \mathrm{min}$. Degradation acidic byproducts formation was verified by means of $\mathrm{pH}$ measurements, and it was found that $\mathrm{pH}$ rapidly decreases with time in semi batch experiments up to 3 .

- The results indicate that semi batch subcritical hydrolysis of Kikuyu grass, an abundant lignocellulose residue currently discarded in sanitary landfills without any utilization, is an efficient technology to produce hydrolysates with a high concentration of reducing sugars. The issue still remains of the fermentation inhibitory effect of sugars and lignin decomposition products which needs to be further addressed.

\section{ACKNOWLEDGES}

The authors wish to thank the Colombian Institute of Science and Technology (COLCIENCIAS) for a young researcher grant awarded to engineer Paola Marulanda to carry out research at Universidad de La Salle in Bogotá for one year.

\section{REFERENCES}

Abdelmoez, W., Nage, S. M., Bastawess, A., Ihab, A., \& Yoshida, H. (2014). Subcritical water technology for wheat straw hydrolysis to produce value added products. Journal of Cleaner Production, 70, 68-77. DOI: 10.1016/j. jclepro.2014.02.011

Cantero, D. A., Dolores Bermejo, M., \& José Cocero, M. (2013). High glucose selectivity in pressurized water hydrolysis of cellulose using ultra-fast reactors. Bioresource Technology, 135, 697-703. DOI: 10.1016/j.biortech.2012.09.035

Cantero, D. a., Tapia, Á. S., Dolores Bermejo, M., \& José Cocero, M. (2015). Pressure and temperature effect on cellulose hydrolysis in pressurized water. Chemical Engineering Journal, 276, 145-154. DOI: 10.1016/j. cej.2015.04.076

Cardenas-Toro, F. P., Forster-Carneiro, T., Rostagno, M. a., Petenate, A. J., Maugeri Filho, F., \& Meireles, M. A. a. (2014). Integrated supercritical fluid extraction and subcritical water hydrolysis for the recovery of bioactive compounds from pressed palm fiber. The Journal 
of Supercritical Fluids, 93, 42-48. DOI: 10.1016/j. supflu.2014.02.009

Cardona, E. M., \& Rios, L. A. (2012). Disponibilidad de Variedades de Pastos y Forrajes como Potenciales Materiales Lignocelulósicos para la Producción de Bioetanol en Colombia Availability of Grasses and Forages as Potential Lignocellulosic Materials for Bioethanol Production in Colombia, 23, 87-96. DOI: 10.4067/S071807642012000600010

Haghighi Mood, S., Hossein Golfeshan, A., Tabatabaei, M., Salehi Jouzani, G., Najafi, G. H., Gholami, M., \& Ardjmand, M. (2013). Lignocellulosic biomass to bioethanol, a comprehensive review with a focus on pretreatment. Renewable and Sustainable Energy Reviews, 27, 77-93. DOI: 10.1016/j.rser.2013.06.033

King, J. W., Srinivas, K., Guevara, O., Lu, Y. W., Zhang, D., \& Wang, Y. J. (2012). Reactive high pressure carbonated water pretreatment prior to enzymatic saccharification of biomass substrates. Journal of Supercritical Fluids, 66, 221-231. DOI: 10.1016/j.supflu.2012.02.010

Kumar, S., Kothari, U., Kong, L., Lee, Y. Y., \& Gupta, R. B. (2011). Hydrothermal pretreatment of switchgrass and corn stover for production of ethanol and carbon microspheres. Biomass and Bioenergy, 35(2), 956-968. DOI: 10.1016/j. biombioe.2010.11.023

Miller, G. L. (1959). Use of Dinitrosalicylic Acid Reagent for Determination of Reducing Sugar. Analytical Chemistry, 31(3), 426-428. DOI: 10.1021/ac60147a030

Mussatto, S. I., \& Roberto, I. C. (2004). Alternatives for detoxification of diluted-acid lignocellulosic hydrolyzates for use in fermentative processes: A review. Bioresource Technology, 93(1), 1-10. DOI: 10.1016/j. biortech.2003.10.005

Pińkowska, H., Wolak, P., \& Oliveros, E. (2013). Application of Doehlert matrix for determination of the optimal conditions of hydrothermolysis of rapeseed meal in subcritical water. Fuel, 106, 258-264. DOI: 10.1016/j.fuel.2012.12.023

Prado, J. M., Follegatti-romero, L. A., Forster-carneiro, T., Rostagno, M. A., Filho, F. M., \& Meireles, M. A. A. (2014). The Journal of Supercritical Fluids Hydrolysis of sugarcane bagasse in subcritical water. The Journal of Supercritical Fluids, 86, 15-22. DOI: 10.1016/j.supflu.2013.11.018
Prado, J. M., Forster-Carneiro, T., Rostagno, M. a., FollegattiRomero, L. a., Maugeri Filho, F., \& Meireles, M. A. A. (2014). Obtaining sugars from coconut husk, defatted grape seed, and pressed palm fiber by hydrolysis with subcritical water. Journal of Supercritical Fluids, 89, 89-98. DOI: 10.1016/j.supflu.2014.02.017

Prado, J. M., Lachos-perez, D., Forster-carneiro, T., \& Rostagno, M. A. (2015). Food and Bioproducts Processing Sub- and supercritical water hydrolysis of agricultural and food industry residues for the production of fermentable sugars : A review. Food and Bioproducts Processing, 98, 95-123. DOI:10.1016/j.fbp.2015.11.004

Sasaki, M., Adschiri, T., \& Arai, K. (2003). Fractionation of sugarcane bagasse by hydrothermal treatment. Bioresource Technology, 86(3), 301-304. DOI: 10.1016/S09608524(02)00173-6

Schacht, C., Zetzl, C., \& Brunner, G. (2008). From plant materials to ethanol by means of supercritical fluid technology. Journal of Supercritical Fluids, 46, 299-321. DOI: 10.1016/j.supflu.2008.01.018

UAESP. (2010). Programa para la gestión de residuos sólidos orgánicos para la ciudad de Bogotá, D.C. Alcaldia Bogota.

Zhao, Y., Lu, W.-J., Wang, H.-T., \& Yang, J.-L. (2009). Fermentable hexose production from corn stalks and wheat straw with combined supercritical and subcritical hydrothermal technology. Bioresource Technology, 100(23), 5884-9. DOI: 10.1016/j.biortech.2009.06.079

\section{AUTHORS}

\section{Paola Andrea Marulanda Buitrago}

Affiliation: Environmental and Sanitary Engineering Program, Universidad de La Salle, Bogotá, Cundinamarca, Colombia e-mail: paola.marulanda@gmail.com

\section{Víctor Fernando Marulanda Cardona}

Affiliation: Environmental and Sanitary Engineering Program, Universidad de La Salle, Bogotá, Cundinamarca, Colombia.

e-mail: vfmarulanda@unisalle.edu.co 